\title{
Malignant Fibrous Histiocytoma: A Rare Cause of Rectal Mass
}

\section{Malign Fibröz Histiyositom: Rektumda Kitlenin Nadir Bir Nedeni}

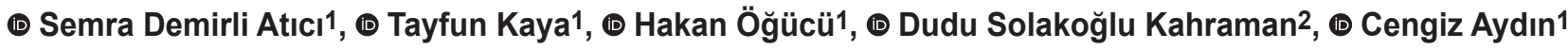 \\ ${ }^{1}$ İzmir University of Health Sciences, Tepecik Training and Research Hospital, Clinic of General Surgery, İzmir, Turkey \\ 2İzmir University of Health Sciences, Tepecik Training and Research Hospital, Clinic of Pathology, İzmir, Turkey
}

\section{HIIIIII| ABSTRACT}

Malignant fibrous histiocytoma is a type of soft tissue sarcoma that originates from mesenchymal tissues and that mostly affects extremities. Abdominal malignant fibrous histiocytoma usually has a poor prognosis and is rarely seen in the rectum. A 52-year-old female patient presented with rectal bleeding, tenesmus and anemia. She was operated for an obstructive rectal mass and postoperative pathology was reported as malignant fibrous histiocytoma. Herein, we aimed to report a case of malignant fibrous histiocytoma, a rare cause of rectal mass, who was treated with abdominoperineal resection + end colostomy.

Keywords: Malignant fibrous histiocytoma, rectal mass, abdominoperineal resection

\section{|l|l||l|| ÖZ}

Malign fibröz histiyositom, sıklıkla uyluk, kalça ve ekstemitelerde görülen bir yumuşak doku sarkomu tipi olup, mezenkimal dokulardan kaynaklanır. Abdominal kaynaklı malign fibröz histiyositom genellikle kötü prognozlu olup, rektumda da çok nadiren gözlenir. Elli iki yaşında kadın hasta, rektal kanama, tenesmus ve anemi semptomları ile başvurdu. Obstruktif rektal kitle nedeniyle opere edilen hastanın postoperatif patolojisi malign fibröz histiositom olarak raporlandı. Biz burada abdominoperineal rezeksiyon + uç kolostomi ile tedavi ettiğimiz, nadir görülen rektal kitlenin bir sebebi olan malign fibröz histiositom olgusunu liteatür eşliğinde sunmayı planladık.

Anahtar Kelimeler: Malign fibröz histiyositom, rektal kitle, abdominoperineal rezeksiyon

\section{Introduction}

Malignant fibrous histiocytoma (MFH), also known as pleomorphic undifferentiated sarcoma, is a type of soft-tissue sarcoma originating from mesenchymal tissues. It is usually seen in the thighs, hips and extremities. ${ }^{1}$ Rectal MFH is an extremely rare condition reported only as a few case reports. Surgical resection is the first choice in the treatment of rectal MFH.

\section{Case Report}

A 52-year-old female patient presented with rectal bleeding, weight loss and tenesmus. She had a history of surgery for endometrial cancer 15 years ago with postoperative chemotherapy and radiotherapy. Her physical examination was unremarkable except for a huge bleeding mass palpated on the posterolateral sidewall of the rectum at a distance of two $\mathrm{cm}$ to anal verge. Laboratory tests revealed anemia (hemoglobin: $6.5 \mathrm{mg} / \mathrm{dL}$ ). Carcinoembryonic antigen, alpha-fetoprotein, carbohydrate antigen 19-9 and other laboratory tests were unremarkable. Colonoscopy revealed a fragile, necrotic mass puffy from the mucosa in the distal rectum at the posterior wall, starting from the $2 \mathrm{~cm}$ distance to anal verge and extending up to $8 \mathrm{~cm}$. Colonoscopic biopsy reported was as an undifferentiated malignant tumor. Abdominopelvic computed tomography

This case report was accepted as a poster presentation in $17^{\text {th }}$ Colorectal Surgery Congress (2019, Antalya, Turkey).

Address for Correspondence/Yazışma Adresi: Semra Demirli Atıcı MD,

İzmir University of Health Sciences, Tepecik Training and Research Hospital, Clinic of General Surgery, İzmir, Turkey 
scan yielded thickening of the posterior rectal wall (Figure 1). Positron emission tomography showed an increased fluorodeoxyglucose uptake in the $5.5 \times 5 \times 5.3 \mathrm{~cm}$ soft tissue lesion in the distal rectum standardized uptake value maximum: 2.7. Abdominoperineal resection with an end colostomy was performed. Intraoperatively, it was observed that the tumor was perforated from the posterior wall of the rectum. The patient was discharged on the $15^{\text {th }}$ postoperative day due to surgical site infection in the postoperative follow-up. Pathological examination revealed $4.5 \times 4 \times 2 \mathrm{~cm}$ ulcerovegetant mass. Cross-sections showed invasion of the colonic mucosa, invading the bunch, and a tumoral tissue consisting of atypical mesenchymal cells with multiple eosinophilic cytoplasms with prominent nuclei (Figures 2 and 3). In addition, a large number of mitotic figures were observed in the tumor (20 mitoses in 10 large magnification areas). Immunohistochemical staining showed a positive reaction of tumor cells with CD68, Vimentin and focal smooth muscle actin (Figure 4). These

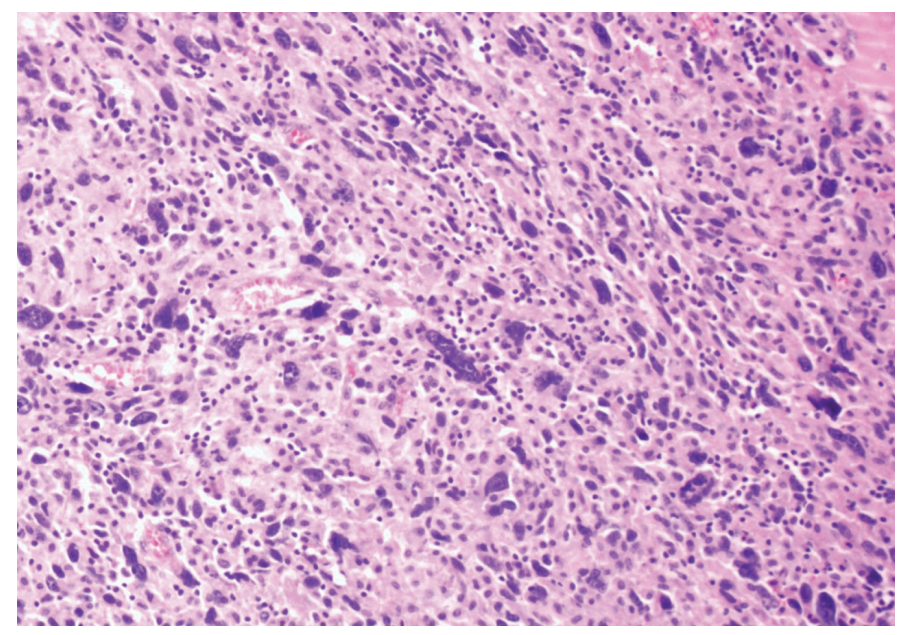

Figure 1. Tumor pleomorphic cells, hematoxylin and eosin, x200

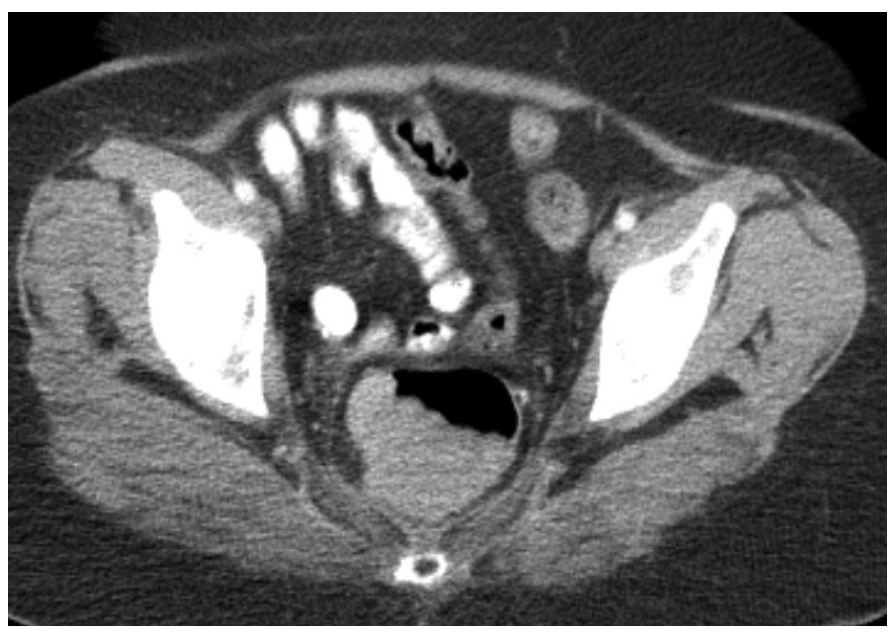

Figure 2. Abdominopelvic computerized tomography scan showed the thickening of the posterior rectal wall findings, in ombination with the histomorphology and immunohistochemical staining evaluations, were consistent with MFH of the rectum. Written informed consent was obtained from the patient for publication of this case report and any accompanying images.

\section{Discussion}

MFH, also known as pleomorphic undifferentiated sarcoma, originates from mesenchymal tissues and it was first reported by O'Brien and Stout in 1964., Abdominal-derived MFH usually has a poor prognosis and is rarely seen in the rectum. ${ }^{2,3}$ In their study, Kim et al. ${ }^{3}$ reported that the main age of colorectal MFH was 62 years (range, 12-85) with only two pediatric cases. However, our patient was female and colorectal MFH was reported to have a male predominance according to the reported cases of 19 male patients. ${ }^{3} \mathrm{MFH}$ is a diagnosis of exclusion from carcinoma, gastrointestinal stromal tumor, sarcoma and malign melanoma by immunohistochemical studies.

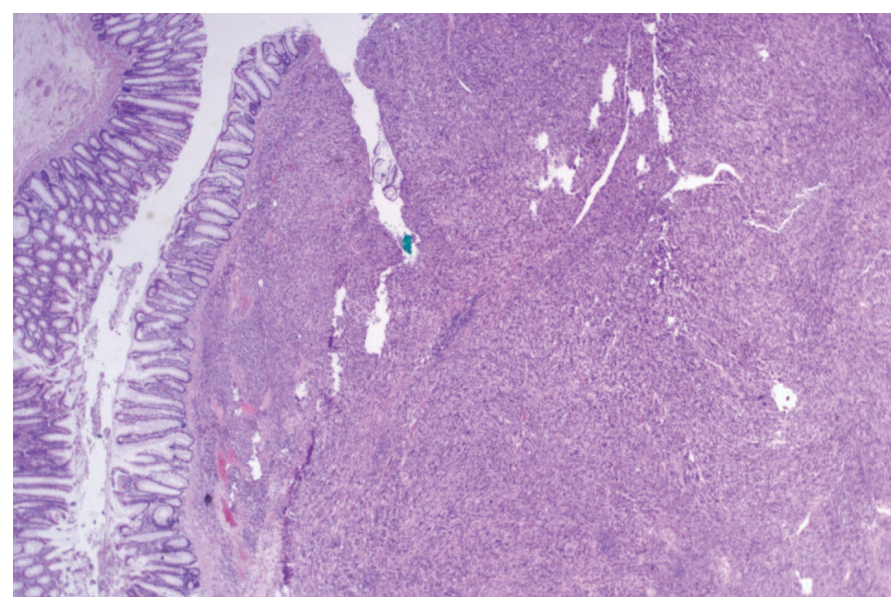

Figure 3. Tumor tissue in diffuse and bundles under the normal rectum mucosa, hematoxylin and eosin, $x 40$

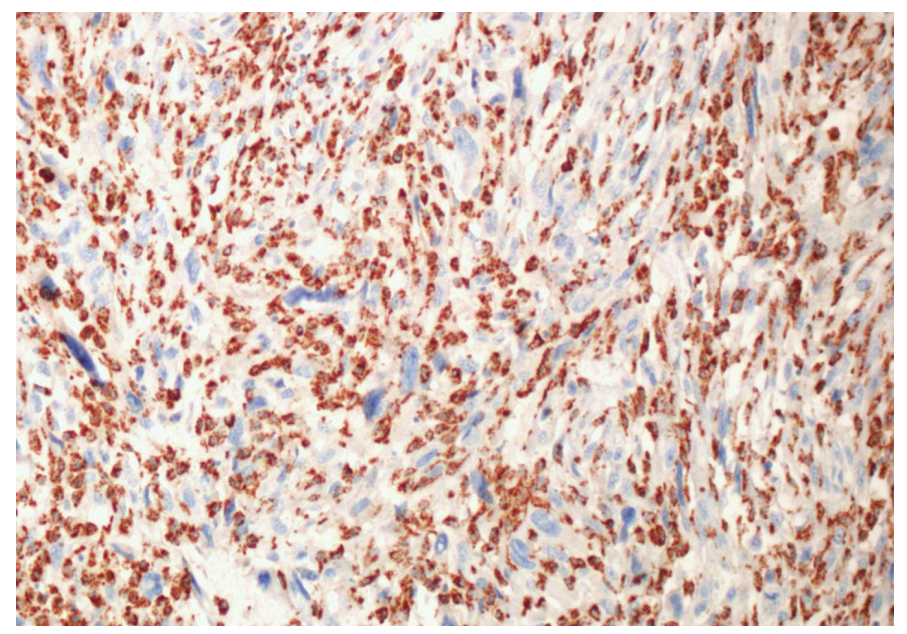

Figure 4. Immunohistochemical staining showed a positive reaction of tumor cells with CD68, diaminobenzidine x200 
Immunohistochemical tests are helpful to differentiate MFH. Carcinoma can be excluded with cytokeratin (CK) PanCK, CK7, CK20 negativity; gastrointestinal stromal tumor can be excluded with CD34 and CD117 negativity, and malign melanoma can be excluded with Melan-A, S100 and HMB45 negativity. ${ }^{2,3}$ MFH cells often express CD68. However, CD68 may be interpreted as positive due to relatively high number of tumor-infiltrating histiocytes in $\mathrm{MFH}^{3}{ }^{3}$ There are many predisposing factors such as genetic factors, chemical carcinogens, chronic inflammation and lymphedema for this rare tumor type. ${ }^{2,3,4}$ History of radiotherapy and chemotherapy is also a risk factor, as in our case who was operated due to endometrial cancer. ${ }^{2,3}$ Surgical resection with negative margins and a combination of adjuvant treatment modalities are the first choice for the treatment of localized rectal MFH. For the metastatic disease, standard treatment is chemotherapy although the outcome is poor. ${ }^{4}$ In most reported cases, patients with rectal MFH were treated by abdominoperineal resection with an end colostomy. However, Kim et al. ${ }^{3}$ reported a patient who refused abdominoperineal resection and had a combination of transanal excision with postoperative radiotherapy without local recurrence or distant metastasis for 15 months. However, the role of adjuvant chemotherapy in the treatment remains unclear and adjuvant radiotherapy is recommended for local control in patients with high-grade sarcoma. In addition to these current treatment modalities for MFH, Boxberg et al. ${ }^{5}$ suggested immunotherapy including program death ligand (PD)-1 and its PD-ligand 1. In conclusion, because of the rarity of rectal MFH, larger case series may help for the better understanding of the treatment modalities without local recurrence for this disease.

\section{Ethics}

Informed Consent: Written informed consent was obtained from the patient for publication of this case report and any accompanying images.

Peer-review: Internally peer-reviewed.

\section{Authorship Contributions}

Surgical and Medical Practices: T.K., S.D.A., Concept: S.D.A., H.Ö., Design: S.D.A., C.A., Data Collection or Processing: H.Ö., D.S.K., Analysis or Interpretation: T.K., C.A., Literature Search: S.D.A., T.K., Writing: S.D.A.

Conflict of Interest: No conflict of interest was declared by the authors.

Financial Disclosure: The authors declared that this study received no financial support.

\section{References}

1. Goldblum JR, Weiss SW. Enzinger and Weiss's Soft Tissue Tumors. $6^{\text {th }}$ ed. Elsevier; 2014

2. Ozzello L, Stout AP, Murray MR. Cultural characteristics of malignant histiocytomas and fibrous xanthomas. Cancer 1963;16:331-344.

3. Kim BG, Chang IT, Park JS, Choi YS, Kim GH, Park ES, Choi CH. Transanal excision of a malignant fibrous histiocytoma of anal canal: A case report and literature review, World J Gastroenterol 2008;14:1459-1462.

4. Nascimento AF, Raut CP. Diagnosis and management of pleomorphic sarcomas (so-called 'MFH') in adults. J Surg Oncol 2008;97:330-339.

5. Boxberg $\mathrm{M}$, Steiger $\mathrm{K}$, Lenze $\mathrm{U}$, Rechl $\mathrm{H}$, von Eisenhart-Rothe $\mathrm{R}$, Wörtler K, Weichert W, Langer R, Specht K. PD-Ll and PD-1 and characterization of tumor-infiltrating lymphocytes in high grade sarcomas of soft tissue - prognostic implications and rationale for immunotherapy. OncoImmunology 2017;7:e1389366. 